\title{
The irritable bowel controversy
}

\section{By J. F. FIELDING, fervis Street Hospital, Dublin, Irish Republic}

The irritable bowel controversy starts with definitional problems and in no way abates when one considers the role of a dietary-fibre-deficient diet in the precipitation of the irritable bowel syndrome and the efficacy of increasing dietary fibre in patients with the syndrome.

When Dr Jones discusses his irritable bowel syndrome patients can we assume that he is describing the same disorder as Dr Smith's patients with irritable bowel syndrome (Drossman, 1983)? Until definite diagnostic criteria are to hand it is less rather than more likely that the answer is in the affirmative. Most people discuss subsets of patients with predominantly colonic symptoms (Chaudhary et al. I 962; Cann et al. 1984; Thompson, 1984) whereas more define subsets as they predominantly affect different parts of the gastrointestinal tract (Fielding, 1982). Most consider the efficacy of treatment in relation to varying 'colonic' symptoms whereas others, struck by the homogeneity of the irritable colon subgroup of the irritable bowel syndrome (Fielding, I $98_{3}$ ) are more interested in global response. The diagnosis may be based on exclusion (Drossman, 1983) or made positively (Fielding, 1983).

The most popular definition of dietary fibre is 'the plant polysaccharides and lignin which are resistant to hydrolysis by the digestive enzymes of man' (Trowell et al. 1976). More recently the term edible fibre has been proposed (Trowell $e t$ al. 1978) to encompass all ingested substances which enter the colon more or less intact, including food additives such as guar gum and therapeutic agents such as ispaghula husk or granules and the mucilages of psyllium seeds. The effects of dietary fibre on colonic function are due to both its physical and chemical properties and vary with the individual and the type of fibre, its physical form and the amount ingested (Cummings \& Stephen, 1980). There may also be endocrine (Commell et al. 1980) and exocrine (Stock-Dange et al. 1983) effects.

There is controversy as to whether fibre-depleted diets increase the risk of developing the irritable bowel syndrome (Brukitt et al. 1972; Fielding \& Melvin, 1979; Hillman et al. 1982).

Some trials have found that irritable bowel syndrome patients have benefited from the use of dietary fibre (Manning et al. 1977; Fielding \& Kehoe, 1980), others have noted no more than placebo response (Soltoft et al. 1976; Cann et al. 1984). It is unlikely, however, that the dietary fibre effect is purely a placebo effect (Fielding \& Kehoe, r 984 ). Bulking agents have been regarded as beneficial (Richie \& Truelove, 1980) and without effect (Longstreth et al. 1981; Arthurs \& Fielding, 1983). There has been no perfect trial. 
Consensus at this point in time would suggest that those irritable bowel syndrome patients most likely to benefit from increasing their fibre intake are those whose predominant abnormality of bowel habit is constipation. There is some evidence that flexible fibre intakes and flexible alterations in fibre intake may also be beneficial.

\section{REFERENCES}

Arthurs, Y. \& Fielding, J. F. (1983). Irish Medical fournal 76, 253.

Brukitt, D. P., Walker, A. R. P. \& Painter, N. S. (1972). Lancet ii, 1408-14I I.

Cann, P. A., Reed, N. W. \& Holesworth, C. D. (1984). Gut 25, 168-173.

Chaudhary, N. A. \& Truelove, S. C. (1962). Quarterly Journal of Medicine 31, 307-322.

Commell, A. M., McCarroll, A. M. \& Chen, M. H. (1980). Irish fournal of Medical Science 149, 49-52.

Cummings, J. H. \& Stephen, A. M. (1980). Canadian Medical Association fournal 23, I109-III4.

Drossman, D. A. (1983). Fournal of Clinical Gastroenterology 5, 489-492.

Fielding, J. F. (1982). Acta Gastroentrologica Belgica 45, 477-484.

Fielding, J. F. (1983). Fournal of Clinical Gastroenterology 5, 495-497.

Fielding, J. F. \& Kehoe, M. (1980). Irish fournal of Food Science and Technology 4, 89-92.

Fielding, J. F. \& Kehoe, M. (1984). Irish Fournal of Medical Science 153, 178-180.

Fielding, J. F. \& Melvin, K. (1979). Fournal of Human Nutrition 33, 243-247.

Hillman, L. C., Stace, W. H., Fisher, A. \& Pomare, E. W. (1982). American fournal of Clinical Nutrition 36, 626-629.

Lonstreth, G. F., Fox, D. D., Youkeles, L., Forsythe, A. B. \& Wolochow, D. A. (1981). Annals of Internal Medicine 95, 53-56.

Manning, A. P., Heaton, K. W., Harvey, R. F. \& Uglow, P. (1977). Lancet ii, 417-418.

Richie, J. A. \& Truelove, S. C. (1980). British Medical fournal 281, I3 17-1319.

Soltoft, J. I., Gudmand-Hoyer, E., Krig, B. Kristensen, E. \& Wolf, H. R. (1976). Lancet i, $270-272$.

Stock-Dange, C., Bouchet, P., Dentingur, A., Aprahamian, M. \& Grenier, J. F. (I983). American fournal of Clinical Nutrition 38, 843-848.

Thompson, W. G. (1984). Gut 25, 305-320.

Trowell, H. C., Godaling, E., Spiller, G. \& Briggs, G. (1978). American fournal of Clinical Nutrition 31, 1489-1490.

Trowell, H. C., Southgate, D. A. T., Wolever, T. M. S., Leeds, A. R., Gassull, M. A. \& Jenkins, D. J. A. (1976). Lancet $\mathrm{i}, 967$. 